\title{
EVALUASI PELAKSANAAN PROGRAM BAHASA ARAB DI PONDOK PESANTREN AL-AZHAR MALANG
}

\author{
Irfan Ihatif Mashur ${ }^{1}$ Baili $^{2}$ \\ ${ }^{12}$ Pascasarjana UIN Maliki Malang \\ Email: ipank.toliz@gmail.com
}

\begin{abstract}
The purpose of the study was to find out the process of conducting an evaluation of the Arabic Language program in Al-Azhar Islamic boarding school. In this study using a type of qualitative descriptive research, as an instrument that researchers conduct observations and interviews directly with educators, students and related parties as a source of data in this study, and as additional data, namely study documents. This study concludes that the implementation of program evaluations at the poor al-Azhar boarding school uses a discrevancy model or gap model, a Goal-Oriented Evaluation Model and a Decision-Oriented Evaluation Model.
\end{abstract}

Keyword: Evaluation, program implementation, Arabic language

\begin{abstract}
ABSTRAK
Tujuan dari penelitian ialah untuk mengetahui proses pelaksaan evaluasi program Bahasa Arab di pondok pesantren Al-azhar. Dalam penelitian ini mengunakan jenis penelitian deskriftif kualitatif, sebagai instrumennya yakni peneliti melakukan observasi dan wawancara langsung kepada pendidik, peserta didik dan pihak-pihak yang terkait sebagai sumber data dalam penelitian ini, dan sebagai data tambahan yakni study dokumen. Penelitian ini menyimpulkan bahwa, pelaksanaan evaluasi program dipondok pesantren al-azhar malang mengunakan model discrevancy atau model kesenjangan, Model Evaluasi Berorientasi Tujuan dan Model Evaluasi Berorientasi Keputusan.
\end{abstract}

Kata kunci: Evaluasi, Manajemen Program, Bahasa arab

\section{PENDAHULUAN}

Evaluasi yang paling banyak dan sering dipahami oleh orang-orang adalah evaluasi yang hanya berkaitan pada penilaian saja, penilaiannya bisa berupa sumatif dan formatif. Jika penilaian sudah terlaksanakan, evaluasi dianggap sudah dilakukan. Hal ini bertolak belakang dengan evaluasi program, dalam evaluasi program tidak cukup hanya melihat dan difokuskan dari aspek penilaiannya saja akan tetapi ada banyak faktor yang dapt dilihat untuk mengukur berhasil atau tidaknya suatu program. ${ }^{1}$

Evaluasi program merupakan rangkaian kegiatan yang sistematis dalam rangka mencari informasi tentang hasil kinerja dan kriteria yang menjadi standar

1 Ashiong P. Munthe, pentingnya evaluasi program di institusi pendidikan, Jurnal Scholaria, vol. 5, No. 2, 2015 
yang telah ditetapkan sebelumnya guna mengatasi masalah-masalah, ataupun kendalam dalam pelaksanaan program ${ }^{2}$

Widyoko mengatakan: di dalam manajemen, evaluasi merupakan satu kesatuan yang saling berhubungan dengan lainnya dalam upaya apapun yang telah diprogramkan, tak terkecuali bagi program pembelajaran yang merupakan bagian dari program pendididikan dalam arti makro. Dalam pengertian lain, evaluasi dimakanai sebagai dasar dalam menentukan tolak ukur pemberian keputusankeputasan yang berdampak terhadap tujuan yang ingin dicapai dari sebuah program dan pengetahuan tentang gejala-gelala yang dapat mempengaruhi kinerja program. ${ }^{3}$

Dalam pelaksanaanya, sering ditemukan banyak lembaga pendidikan yang memiliki beberapa program yang mana program ini bertujuan untuk menarik perhatian peserta didik agar mendaftarkan diri dan bersaing dengan lembagalembaga yang lain. Namun dalam praktek pelaksanaannya program tersebut belum bisa dikatakan sukses disebabkan kurangnya pengaawasan dan eavaluasi.

Pondok pesantren al-Azhar adalah salah satu pondok yang memiliki sebuah program yaitu program bahasa Arab happy. Berdasarkan hasil observasi sementara, peneliti dapati bahwasanya pelaksanaan program bahasa Arab di pondok pesantren tersebut sudah berjalan dengan baik, para peserta didik tampak belajar dengan antusias dan penuh semangat menjalankan program tersebut.

Berdasarkan data tersebut, peneliti ingin mengkaji lebih mendalam tentang pelaksanaan program bahasa Arab di lembaga tersebut dan peneliti batasi dari aspek evaluasinya kemudian dirangkum dan difokuskan kedalam sebuah judul "evaluasi pelaksanaan program bahasa Arab di pondok pesantren al-Azhar Malang”. Dengan alasan, pondok pesantren ini masih terhitung pondok pesantren yang baru, pada saat ini sudah berjalan hampir dua tahun akan tetapi program bahasa Arabnya sudah bisa berjalan dengan baik. Dalam hal ini tentu adanya proses evaluasi yang dilakukan oleh pimpinan. Penelitian ini bertujuan untuk mengetahui evalauasi pelaksanaan program Bahasa Arab di pondok pesantren alAzhar Malang? Bagaimana kriteria pencapaian program Bahasa Arab Di Pondok Pesantren Al-Azhar Malang. Dengan harapan menjadi pedoman bagi lembagalembaga pendidikan yang lain dalam mengevaluasi sebuah program.

2 Rusydi Ananda \& Tien Rafida, pengantar evaluasi program pendidikan, (Medan: perdana publishing, 2017), hlm. 6

${ }^{3}$ Fitri Mawaddah Bako dkk, pengawasan dan evaluasi program Bahasa Arab di pondok pesantren,( jurnal imla', vol. 3, No. 1, 2018) 


\section{PENGERTIAN EVALUASI}

Evaluasi dalam suatu Lembaga merupakan hal yang harus ada, baik dalam sebuah Lembaga Pendidikan formal ataupun lembaga Pendidikan nonformal, Lembaga pemerintahan ataupun Lembaga masyarakat tertentu sebagai bagian dari sebuah manajemen program. Evaluasi merupakan asal kata serapan dari kata evalution. menurut kamus KBBI "Evaluasi adalah penilaian"." Menurut arikunto dan Jabar dalam Rusydi Ananda, akar kata evaluasi berasal dari bahasa Inggris yaitu "evaluation", kemudian diadopsi kedalam Bahasa Indonesia dengan tetap menyesuaikan kedalam bentuk kata aslinya. ${ }^{5}$ Pada setiap Lembaga pendidkan formal ataupun non formal tentu memiliki standar penilain dalam mengukur keberhasilan system pendiidkan sebagai hal yang ingin dicapai dalam tujuan yang telah dirumuskan. sedangkan evaluasi menurut Abdullah adalah "penilaian terhadap sesuatu yang dilengkapi dengan obyek yang dinilai Misalnya evaluasi pembelajaran dimadrasah ibtidayyah, madrasah tsanawiyyah, madrasah Aliyah dan yang setara dengan ketiga Pendidikan tersebut. ${ }^{6}$

\section{TUJUAN DAN MANFAAT EVALUASI PROGRAM}

Purwanto dan Suparman memaparkan beberapa tujuan evaluasi sebagai sebuah system yang sangat berperan dalam tercapainya suatu tuajuan lembaga, diantaranya:

1. Sebagai informasi kepada masyarakat social tentang keberhasilan program yang telah dijalankankan sehingga menjadi motivasi kepada masyarakat luas untuk memberikan kesempatan kepada anak-anak mereka dalam melanjutkan studi kedepannya. khususnya bagi mereka yang ingin membentuk karakter agamis seorang anak. dengan memberikan informasi yang mendalam mengenai hasil dari program yang dijalankan kepada masyarakat itu lebih efektif dari sekedar memberikan nilai berupa angka ${ }^{7}$.

2. Sebagai dasar informasi bagi kepala Yayasan ,pendidik dan seluruh pihak terkait dalam memberikan keputusan. Dengan adanya hasil evalusi sebagai rujukan atau pijakan dalam menindak lanjuti program yang telah dijalankan, apakah program tersebut patut untuk dilajutkan ataukah program tersebut harus diberhentikan sebab tak tercapainya tujuan yang telah dirumuskan sebelumnya. beberapa alasan yang memungkinkannya

\footnotetext{
${ }^{4}$ KBBI online. https://kbbi.web.id/evaluasi. Diakses pada tgl 15/04/2019.

5 Rusydi Ananda \& Tien Rafida, pengantar evaluasi program pendidikan, (Medan:

6 ma'ruf Abdullah. Manajemen dan evaluasi kinerja karyawan,( Yogyakarta: Aswaja Pressindo, 2014)

7 Purwanto dan Suparman, A.. Evaluasi Program Diklat.( Jakarta:STIA-LAN Press, 1999)
} perdana publishing, 2017), hlm. 1 
untuk diberhentikan diantaranya: programnya sudah lawas sehingga tak sesuai dengan Pendidikan masa kini, hasilnya tak sesuai dengan tujuan program yang telah diwacanakan, dan adanya fenomena yang bisa membuat program tersebut harus diperbaharui ${ }^{8}$

3. Sebagai pelengkap bagi program sebelumnya. Dengan adanya evaluasi terhadap program yang ada maka akan diketahui kelemahan-kelemahan yang terdapat didalamnya sehingga dapat dilengkapi kelemahan tersebut, ataukah terdapat kendala-kendalan dalam proses pelaksanaannya sehingga dapat diberikan solusi, ataukah terdapat kesenjangan antara pelaksanaan dengan tujuan program sehingga dicari akar masalahnya dan dipecahkan. Tujuannya agar program yang sudah ada sebelumnya dapat berjalan efektif dan hasilnya dapat diukur sejauh mana efektifitasnya dalam proses pelaksanaannya.

4. Sebagai upaya dalam meningkatkan keterlibatan masyarakat dalam pelaksanaan, pengembangan dan pertumbuhan program. Dari hasil evaluasi dapat memberikan informasi mengenai kesuksesan terhadap pelaksanaan program dalam suatu lembaga sehingga masyarakat ataupun kalangan mahasiswa terpanggil dalam rangka mengembangkan dengan melakukan penelitian terhadap program didalamnya. Dari hasil penelitian, dapat dijadikan landasan dalam mengembangkan program yang lebih baik lagi.

\section{KARAKTERISTIK EVALUASI PROGRAM}

Pelaksanaan evaluasi program dalam suatu Lembaga, khususnya Lembaga Pendidikan memiliki corak tersendiri yang membedakannya dengan lainnya. Diantaranya berupa karakteristik yang menjadi pembeda satu sama lainnya. Menurut arikunto dan jabar bahwa evaluasi program memiliki delapan karakteristik yang kesemuanya berhubungan satu dan lainnya. Diantaranyya:

1. Dalam pelaksanaan evaluasi kaidah-kaidah penelitian merupakan pijakan dalam melakukan evaluasi. Bukan evaluasi yang didasarkan atas kehendak sendiri.

2. Proses evaluasi program merupakan kegiatan yang sistematis dan terkonsep sehingga pelaksanaannya harus dirancang sedemikian rupa sesuai dengan urutannya atau secara bertahap berdasarkan urutannya masing-masing bukan dengan yang termudah yang berdasarkan keinginan pelaksana evaluasi.

${ }^{8}$ Umi Hasanah, et al.. Analisis Pelaksanaan Evaluasi Pembelajaran Biologi Kelas X Semester Genap 2013/2014 Di Sman Kota Blitar. Jurnal Pendidikan Biologi Volume 7, Nomor 1. 
3. Adanya indikator-indikator yang menjadi penentu terhadap keberhasilan program sebagai objek penting yang harus dikaji dan dianalisis secara mendalam.

4. Hasil evaluasi merupakan hasil dari perbandingan teori dan data yang ditemukan dilapangan dengan mengunakan standar, ukuran dan kriteria pencapain masing-masing program.

5. Tiap-tiap kebijakan atau rencana program harus berdasarkan hasil evaluasi atau hasil penelitian. Dengan kata lain, bahwasanya kebijakan atau tindak lanjut yang berkenaan dengan pelaksanaan program kedepannya harus menyesuaikan dengan hasil evaluasi.

6. Pelaksanaan evaluasi program merupakan kegiatan evaluasi yang dimulai dari identifikasi komponen-komponen program hingga sub komponen program agar hasil evaluasi mampu menggambarkan secara rinci atau detail kondiri nyata dari program yang terlaksana.

7. Pelaksanaan evaluasi yang diterapkan pada indikator-indikator yg terkecil dengan mengunakan kriteria dan standar evaluasi yang semestinya agar dapat diketahui kelemahan-kelemahannya, baik hal yang bersifat sederhana ataupun yang kecil.

8. memberikan tindak lanjut yang berdasarkan hasil rekomendasi terhadap hasil evaluasi program yang ingin dikembangkan atau diganti dengan program yang lain ${ }^{9}$

\section{MODEL-MODEL EVALUASI PROGRAM}

Dalam evaluasi program antara suatu Lembaga dengan lembaga tertentu memiliki perbedaan satu dan yang lainnya, baik dalam hal perencanaannya, pelaksanaannya ataupun pengawasaannya sehingga melahirkan pandanganpandangan yang berbeda mengenai model evaluasi yang efektif dalam mengevaluasi program tersebut. Diantara model-model evaluasi program sbb:

\section{Model Kesenjangan}

Pelaksanaan evaluasi model kesenjangan merupakan evaluasi yang didasari atas dasar kesenjangan yang terjadi dalam pelaksanaan program sehingga butuh solusi dan pemecahan terhadap masalah didalamnya. Dalam hal ini, antara kinerja atau hasil tak sejalan dengan kreteria yang telah ditetapkan selama proses pelaksanaan program. Dalam pelaksanaan program Pendidikan diantara yang dapat dievaluasi sebagai berikut: ketidaksesuaian antara pelaksanaan program dan rencana program; ketidaksesuaian antara yang diinginkan dan realisasinya;

\footnotetext{
${ }^{9}$ Arikunto, S., dan Jabar, C.S.A. (2009). Evaluasi Program Pendidikan.Pedoman
} Teoretis Praktis Bagi Mahasiswa Dan Praktisi Pendidikan.Jakarta: Bumi Aksara. 
ketidaksesuaian antara tujuan dan pelaksanaan program; dan ketidaksesuain antara standar pencapaian dan hasil capaian program $^{10}$

\section{Model Evaluasi Formatif-Sumatif}

Berbeda dengan model lainnya, model ini memandang perlu adanya perbaikan-perbaikan terhadap program baik dari sisi dalam maupun dari luar yang dapat mempengaruhi program dan memandang bahwasanya tiap program harus memiliki manfaat yang dapat dilihat secara kasat mata. Model evaluasi formatifsumatif sangat berperan penting dalam pengembangan kurikulum dari suatu program sebab mengedepankan terhadap pengembangan program dan mamfaat yang dapat dirasakan dari pengembangan program tersebut ${ }^{11}$

\section{Model Pengukuran}

sebagai salah satu model dalam pelaksanaan evaluasi program maka model pengukuran merupakan model evaluasi yang memprioritaskan kuantitas suatu objek dalam bentuk pengukuran. Model pengukuran atau yang lazim dikaitkan dengan sebutan penilaian terhadap suatu atribut tertentu dengan mengunakan standar yang telah ditentukan sebelumnya. Dalam dunia Pendidikan, model pengukuran terkadang digunakan dalam mengukur perbedaan antara satu individu dengan individu lain. Sebagai permisalan dalam keperluan seleksi individu agar dapat diketahui minat, bakat, serta kemampuan kognitif peserta didik. Model pengukuran disini, berupaya melihat letak perbedaan antara objek yang satu dengan objek lainnya berdasarkan hasil dari pengukuran atau penilain. Perbedaan-perbedaan tersebut dapat diketahui dalam bentuk kuantitas dengan merujuk kepada standar yang telah disepakati ${ }^{12}$

\section{Model Evaluasi Bebas Tujuan}

Dalam pelaksanaan evaluasi bebas tujuan, bentuk evaluasi tidak memprioritaskan tujuan program sebagai dasar pelaksanaan evaluasi melainkan tujuan hanya sekedar formalitas semata. Dalam pelaksanaan evaluasi bebas tujuan hal yang terpenting bagi evaluator ialah mengetahui dampak negative dari suatu program atau pengarug- pengaruh yang berdampak terhadap hasil dari program yang dijalankan sebelumnya. Meminimalisir dampak atau bias dan meningkatkan objektivitas program merupakan fungsi dari evaluasi bebas tujuan.

10 Fernandes, H.J.X. 1984. Evaluation of Educational Program. Jakarta : National Education Planning, Evaluation and Curriculum Development.

${ }^{11}$ Fitri Mawaddah Bako et.al. Pengawasan Dan Evaluasi Program Bahasa Arab Di Pondok Pesantren Arabi: Journal of Arabic Studies Vol. 3 No. 1. 2018

${ }^{12}$ Edi Setyawan, Cahya. 2015. Desain Evaluasi Program Pembelajaran Bahasa Arab. Jurnal Komunikasi dan Pendidikan Islam, Volume 4, Nomor 1, Juni 2015 
Sedang Menurut Issac dan Michael ada 6 model evaluasi, ia mengklasifikasikan model tersebut dalam beberapa bagian, diantaranya:

\section{Model Evaluasi Berorientasi Tujuan.}

Menurut model ini evaluasi dilakukan secara continue dan berkesinambungan. tujuannya adalah untuk mengukur sejauh mana program telah tercapai.

\section{Model Evaluasi Berorientasi Keputusan.}

Evaluasi diorientasikan guna memberikan pertimbangan dan masukan dalam pembuatan serta pengambilan keputusan.

\section{Model Evaluasi Transaksional.}

Evaluasi bertujuan untuk mendeskripsikan sebuah kuantitas dari sebuah program yang dilakukan oleh masyarakat social atau para ahli dalam rangka mengetahui sejauh mana keefektifan sebuah program.

\section{Model Penelitian Evaluasi.}

Evaluasi ini memaparkan tentang dampak dari sebuah system kependidikan dan pandangan-pandangan dalam menentukan strategi pembelajaran kedepannya.

\section{Model Evaluasi Bebas Sasaran.}

merupakan bentuk evaluasi yang tidak memprioritaskan tujuan program sebagai dasar pelaksanaan evaluasi melainkan tujuan hanya sekedar formalitas semata. Dalam pelaksanaan evaluasi bebas tujuan hal yang terpenting bagi evaluator ialah mengetahui dampak negative dari suatu program atau pengarugpengaruh yang berdampak terhadap hasil dari program yang dijalankan sebelumnya.

\section{Model Evaluasi Adversary}

Model ini mengemukakan masalah-masalah yang tampak dalam proses pelaksanaan evaluasi program kemudian memaknai hasil kuantitas dari sebuah program dalam bentuk penilaian dengan menggunakan beberapa informasi yang berbeda dalam satu program yang sama. ${ }^{13}$

\section{METODE PENELITIAN}

Penelitian ini mengunakan metode penelitian deskriftif kualitatif. Adapun penelitian deskriftif kualitatif ialah penelitian dengan cara mengambarkan atau memaparkan perihal-perihal yang berkaitan dengan objek penelitian. Sebagaimana pemaparan Ibrahim bafaadal et al bahawasanya "alasan pengunaan penelitian kualitatif sebab ingin memaparkan hasil penelitian secara prosudural

${ }^{13}$ Issac, S. dan Michael, W.B, Handbook in Research and Evaluation for Education and Behavioral Sciences, (San Diego: Edits Publisher. 1984), hlm. 6-7 
mengenai hasil pelaksanaan manajemen $\operatorname{program}^{14}$ " Adapun teknik pengumpulan data adalah dengan observasi, dokumentasi, dan wawancara.

\section{HASIL PENELITIAN}

\section{Program bahasa Arab pondok pesantren al-Azhar Malang}

Sebelum peneliti membahas program bahasa Arab di pondok pesantren alAzahar Malang, peneliti akan menceritakan sekilas tentang pondok tersebut. Pondok pesantren al-Azhar Malang merupakan cabang dari lembaga kursus alAzhar Pare, pondok ini pada awalnya juga merupakan lembaga kursus kemudian dijadikan pondok berdasarkan kebutuhan masyarakat setempat dengan menambah program tahfiz al-quran, fiqih ibadah tapi yang lebih diperioritaskan adalah program bahasa Arab sehingga pondok ini juga disebut dengan pondok tahfiz dan bahasa Arab al-Azhar Malang. Masing-masing program memiliki Pembina/ustadz sebagai penanggungjawab sekaligus merangkap menjadi pendidik dengan tujuan agar memudahkan bagi pimpinan untuk menanyakan tentang perkembangan program-program tersebut.

Program bahasa Arab di pondok pesantren al-Azhar Malang pada umumnya sama dengan program yang ada pada Lembaga lainnya. Namun yang menjadi ciri khas dari program bahasa arab dipondok al-azhar yakni diadopsi dalam bentuk permainan atau dikenal dengan program bahasa Arab happy sekaligus menjadi program unggulan dalam pembelajaran bahasa arab dipondok tersebut. Bahasa Arab happy, dalam pelaksanaannya dikemas dengan berbagai macam permainan agar peserta didik tidak merasa bosan dalam proses pembelajaran.

Kegiatan dari program bahasa Arab happy ini adalah ilqau al-mufradat, muhadatsah yang meliputi (debat, diskusi, cerita, pidato, presentasi), qawaid, ibarah qashirah dan qiraatul kutub. Kegitannya dilakasanakan dari pagi hingga malam, yang pertama dimulai dari shalat tahajud dilanjutkan shalat shubuh berjamaah, setelah subuh diadakan muhadatsah dan sesekali qaraatul kutub kemudian istirahat. Pada jam 07.00-08.00 dilanjutkan kegiatan ilqau al-mufradat, jam 08.00-09.00 muhadatsah kembali sampai selesai, jam 09.30-10.30 diisi dengan qawaid dan jam 10.30-11.30 dilaksanakan kembali muhadatsah kemudian baru isoma. Kegiatan bahasa Arab dilanjut lagi pada jam 15.00-16.30 berupa muhadatsah setalah itu diteruskan setalah shalat maghrib jam 18.30-19.30 yang diisi dengan ibarah qashirah, setelah shalat isya yaitu jam 20.00-21.00 diisi dengan kajian kitab serta praktek qiraahnya setelah itu istirahat.

14 Ibrahim Bafadal. Pelaksanaan supervisi manajerial dalam rangka implementasi manajemen berbasis sekolah jurnal administrasi dan manajemen pendidikan, volume 1, nomor 2 juni 2018 


\section{Bentuk evaluasi program bahasa Arab pondok pesantren al-Azhar Malang}

Berdasarkan hasil penelitian yang dilakukan oleh peneliti dengan mengunakan wawancara kepada pimpinan pondok dan ustadz yang mengajarkan bahasa Arab peneliti mengetahui bahwasanya bentuk evaluasi program bahasa Arab di pondok pesantren al-Azhar Malang adalah evaluasi bulanan. akan tetapi, ketika mendapati permasalahan yang lebih serius evaluasinya tidak menunggu satu bulan melainkan dalam satu minggu langsung diadakan evaluasi. tapi hal ini jarang terjadi. yang lebih rutin adalah evaluasi bulanan. Evalauasi ini berlaku juga untuk program pondok yang lain yaitu tahfiz quran dan fiqih. Jadi, semua program yang ada di pondok ini dievaluasi dalam satu waktu di forum rapat.

Pada saat evalausi, pimpinan memimpin secara langsung proses evaluasi. Pertama, pimpinan membuka forum kemudian mempersilahkan kepada para Pembina/ustadz memberi laporan tentang programnya baik berupa kendalakendala, masukan-masukan, dan lain sebagainya. Kedua, pimpinan merespon semua laporan-laporan dari para ustadz. Ketiga, baik pimpinan maupun para ustadz merumuskan secara bersama-sama keputusan dan solusi-solusi dari laporan-laporan yang ada.

\section{Kriteria pencapaian program bahasa Arab pondok pesantren al-Azhar Malang}

Dari hasil wawancara yang peneliti lakukan, kriteria pencapaian program bahasa Arab pondok pesantren al-Azhar malang adalah peserta didik menguasi maharah kalam, maharah qiraah dan maharah kitabah, adapun maharah istima' belum dipikirkan karena pondok ini masih sangat baru.

Kriteria pencapaian dari maharah kalam adalah peserta didik mampu berbicara bebas tentang berbagai macam topik, mampu berpidato dengan menggunakan bahasa Arab. Adapun kriteria pencapaian maharah kitabah yaitu peserta didik mampu membaca teks-teks bahasa Arab dengan baik dan benar sesuai dengan kaidah nahwu. Sedangkan kriteria pencapaian dari maharah kitabah adalah peserta didik mampu menulis dari apa yang didengar atau imla kemudian peserta didik mampu untuk menulis teks-teks bahasa Arab dengan baik dan benar ketika mengarang bebas atau menulis teks sederhana.

\section{PEMBAHASAN}

\section{Program Pondok Pesantren Al-Azhar Malang}

Program bahasa Arab di pondok pesantren Al-azhar Malang adalah program bahasa Arab happy, pada semua kegiatan pembelajarannya diselingi dengan berbagai macam permainan agar peserta didik merasa terhibur dan nyaman dalam proses pembelajaran. Dalam jurnal yang ditulis oleh irna kinayungan et.al dengan judul "Efektivitas penerapan Metode Permainan Happy Kingdom Pada Materi Keanekaragaman Makhluk Hidup Terhadap Aktivitas Dan Hasil Belajar Siswa Smp" sebagai hasil penelitian mengatakan bahawasanya 
pembalajaran happy kingdom mampu meningkatkan gairah peserta didik dalam pembelajaran sehingga peserta didik merasa bahwa belajar itu asyik dan menyenankan. ${ }^{15}$ Berdasarkan keterangan tersebut, dapat ditarik sebuah garis besar bahwasanya pembelajara yang dikemas dalam bentuk permainan atau game lebih efektif dan disenangi peserta didik dari pembelajaran yang dikemas dalam bentuk biasa- biasa saja.

Berdasarkan hasil penelitian, dipondok pesantren al-azhar malang menerapkan sebuah program bahasa arab yang unik dari yang lainnya, yakni Bahasa arab happy. Bahasa Arab Happy adalah program Bahasa arab yang dikemas dalam bentuk permainan atau game, dengan berbagai metode dan strategi penyampaian materi ajar yang kreatif. Hal ini senada dengan teori pembelajaran happy kingdom yang digagas oleh irna kinayungan, dengan pembelajaran berbasis game. Meskipun pembelajaran happy kingdom diperuntukkan dalam pembelajaran sains namun subtansi dalam proses pembelajarannya tetap sama, yakni menciptakan suasana pembelajaran yang menyenangkan.

\section{Proses pelaksanaan evaluasi program pondok pesantren Al-azhar Malang}

Berdasarkan data yang ditemukan dilapangan dengan metode wawancara langsung kepada pihak-pihak terkait diantaranya para pendidik/ustadz bahwasanya pelaksanaan evaluasi program dipondok pesantren al-azhar dilakukan apabila terdapat kesenjangan, kendala, atau masalah dalam proses pelaksanannya. Sebagai perumpamaan adanya kesenjangan antara hasil dan tujuan program, atau kesenjangan antara rencana dan pelaksanaannya sehingga apa yang seharusnya diharapkan dari program tersebut tak dapat dicapai secara maksimal. Dalam hal ini, fenomena yang terjadi dilapangan sejalan dengan teori model evaluasi kesenjangan. Yang mana teori tersebut mengambarkan adanya kesenjangan antara hasil kinerja dan kriteria yang diharapkan. Kesenjangan itu bisa berupa tujuan, rencana, pelaksanaan dan lain sebagainya.

Jadi dapat disimpulkan bahwasannya dalam pelaksanaan evaluasi dipondok pesantren al-azhar malang mengadopsi model evaluasi kesenjangan yang digambarkan dengan adanya factor-faktor yang menjadi dasar pelaksanaan evaluasinya, baik dalam hal pokok permasalahannya sehingga dianggap perlu diadakan evaluasi agar permasalahan-permasalahan, kendala, ataupun kelemahankelemahan yang terdapat didalamnya dapat diberikan solusi atau pemecahan masalah. $^{16}$

${ }^{15}$ Irna Kinayungan, Et. Al, Efektivitaspenerapan Metode Permainan Happy Kingdom Pada Materi Keanekaragaman Makhluk Hidup Terhadap Aktivitas Dan Hasil Belajar Siswa Smp, Journal Of Biology Education 5(3) (2016): 230-236

16 Fernandes, H.J.X. 1984. Evaluation of Educational Program. Jakarta : National Education Planning, Evaluation and Curriculum Development. 
Selain demikian, Pelaksanaan evalauasi program bahasa Arab di pondok pesantren al- Azhar dilaksanakan dalam bentuk rapat bulanan, pimpinana dan para ustadz melakukan musyawarah bersama dalam merumuskan solusi dan membuat keputusan atas permasalahan- permasalahan yang telah dilaporkan oleh para pendidik. Evaluasi seperti ini sesuai dengan model evalausi yang dikemukakan oleh Assac dan Michael. keduanya menggagas 6 model evaluasi program. akan tetapi, evaluasi program bahasa Arab yang ada di pondok pesantren al-Azhar Malang sesuai dengan 2 model dari 6 model yang dikemukakan oleh Assac dan Michael, dua model tersebut adalah, pertama: model evaluasi yang berorientasi pada tujuan, yaitu evaluasi dilakukan secara continue dan berkesinambungan tujuannya adalah untuk mengukur pencapaian dari suatu program, Kedua, model Evaluasi Berorientasi Keputusan, Evaluasi diorientasikan guna memberikan pertimbangan dan masukan dalam pembuatan serta pengambilan keputusan. ${ }^{18}$

Pelaksanaan evaluasi program bahasa Arab di pondok pesantren Al-azhar Malang dipimpin langsung oleh kepala pimpinan dan para ustadz dalam bentuk musyawarah bersama sebelum membuat keputusan untuk program ke depannya.

\section{Kriteria pencapaian program pondok pesantren Al-azhar Malang}

\section{Maharah Al-Kalam}

"Maharah al kalam adalah kemampuan mengungkapkan bunyi bunyi artikulasi atau kata kata untuk mengekspresikan pikiran berupa ide, pendapat, keinginan, atau perasaan kepada mitra bicara." ${ }^{\text {,17 }}$ Berdasarkan uraian diatas, sesungguhnya kemampuan maharah al-kalam dapat diukur atau dinilai berdasarkan kemampuan peserta didik dalam mengungkapkan buah pikiran atau gagasan-gagasan dalam bentuk dialog ataupun percakapan yang terstruktur ataupun percakapan bebas. Sehingga untuk mengetahui kesuksesan sebuah program khususnya dalam pencapaian maharah al-kalam akan sangat mudah sebab adanya ukuran penilain yang menjadi landasan kesuksesan program tersebut.

Sehubungan dengan kriteria pencapain sebuah program yang telah dibahas dalam hasil penelitian maka sudah sangat jelas, bahwasanya standar kriteria pencapain program, terkhusus dalam maharah al-kalam ialah mampunya peserta didik mengungkapkan sebuah gagasan-gagasan ataupun argument kepada lawan bicaranya, baik dalam konteks percakapan bebas ataupun terstruktur.

\section{Maharah Qira'ah}

Sebagai bagian dari empat keterampilan yang harus dicapai maka maharah qira'ah merupakan hal yang sangat urgen dalam pembelajaran Bahasa arab. Lebih lanjut, "Maharah qira'ah adalah kemampuan mengenali dan memahami isi

\footnotetext{
17 Acep Hermawan, Metodologi Pembelajaran Bahasa Arab (Bandung: Remaja Rosdakarya, 2014),135.
} 
suatu yang tertulis dengan melafalkan atau mencernanya di dalam hati." Dalam pembelajaran maharah qira'ah mengenali atau mengidentifikasi suatu bentuk kata, kalimat, ataupun paragraph merupakan tolak ukur dimana peserta didik dapat dikatakan mampu, atau mampu memahami makna dari suatu teks dengan cara mengungkapkan dalam bentuk bacaan sederhana ataupun bacaan Panjang.

Dalam pembelajaran maharah qira'ah dipondok pesantren al-azhar malang sebagai standar kriterian pencapaian maharah kalam ialah mampunya siswa membaca teks-teks nahwu sesuai dengan ketentuan kaidah-kaidah nahwu dan Sharaf. Hal ini senada dengan teori pembelajaran maharah qira'ah sebagai standar kriteria ketuntasannya yakni mampunya siswa mengidentifikasi bentuk kata sesuai dengan kaidah-kaidah nahwu dan memahami kandungan isi dari sebuah konteks dengan cara melafalkan atau menjelaskannya didepan peserta didik lain.

\section{Maharah Kitabah}

Maharah kitabah/menulis ialah "kemampuan dalam mendeskripsikan atau mengungkapkan isi pikiran, mulai dari aspek yang sederhana seperti menulis kata-kata sampai kepada aspek yang kompleks yaitu mengarang."19 Dalam hal ini, peserta didik dituntut agar mampu mengutarakan gagasan-gagasan, atau isi pikiran terhadap topik terkait, dengan cara menulis kalimat-kalimat sederhana, hingga menulis sebuah karangan Panjang Sebagai tolak ukur pencapaian hasil pembelajaran maharah kitabah. Selain aspek menulis susunan kata atau mengarang, maharah kitabah menuntut pula terhadap kemampuan peserta didik didalam menulis indah. Sebagai misal, pembelajaran khat yang menuntut agar siswa mampu menulis indah sesuai dengan tata penulisan khat yang berlaku.

Dalam pembelajaran maharah kitabah dipondok pesantren al-azhar malang, kriteria pencapaian maharah kitabah dapat dilihat dengan mampunya peserta didik dalam menulis teks-teks dengan baik dan benar yang dibacakan oleh pendidik. Dalam hal ini, antara teori yang telah disebutkan sebelumnya memiliki kesamaan dalam aspek kreteria pencapaiannya meskipun tak mencakup keseluruhan dari makna yang terkandung dalam teori sebelumnya. Namun tujuan utama dari maharah kitabah dapat trealisasi.

\section{KESIMPULAN}

Berdasarkan hasil temuan penulis dan beberapa kajian teori terkait, maka Pelaksanaan program evaluasi dipondok pesantren Al-azhar malang mengunakan model discrevancy atau model kesenjangan, hal ini dapat diketahui dengan

\footnotetext{
${ }^{18}$ ibid

${ }^{19}$ Abdal Chaqil Harimi, Pembelajaran Maharah Bahasa Arab Berbasis Inklusif (Analisis Kebutuhan Peserta Didik Tunanetra Dalam Pembelajaran Keterampilan Berbahasa Arab),tarling: journal of language education, Vol. 1 No.2
} 
beberapa aspek. Diantaranya, evaluasi program akan diadakan saat menemukan suatu masalah dalam pelaksanaan program, atau adanya kesenjangan antara kinerja dengan kriteria-kriteria yang telah ditetapkan sebelumnya . dari hal demikian, terkadang evaluasi program diadakan secara dadakan atas kebijakan dari pimpinan. Selain model discrevancy, dalam penerapannya juga mengunakan Model Evaluasi Berorientasi Tujuan dan Model Evaluasi Berorientasi Keputusan. Yakni dengan adanya bentuk evaluasi secara continue atau berkesinambungan guna mengetahui pencapain tujuan dari program, yang dilaksanakan sekali dalam setiap bulannya. Dan setiap orientasi pengambilan keputusan atau kebijakan itu didasarkan terhadap pertimbangan dan masukan dari setiap pelaksana evaluasi dalam hal ini, pendidik dan pimpinan Yayasan.

Dalam pencapaian kriteria ketuntasan pembelajaran, tiap-tiap maharah memiliki standar ketuntasan tersendiri, baik dari aspek maharah kalam, maharah kitabah, ataupun maharah qira'ah. Dalam maharah kalam, sebagai standar ketuntasannya ialah mampunya peserta didik untuk berkomunikasi secara lisan. Sedang dalam maharah kitabah ialah mampunya peserta didik dalam menulis teks arab yang sederhana atau dalam bentuk susunan paragrap. Dan yang terakhir maharah qira'ah, sebagai standar ketuntasannya ialah mampunya peserta didik membaca teks-teks arab sesuai dengan kaidah nahwu dan Sharaf.

\section{DAFTAR PUSTAKA}

Arikunto, S., dan Jabar, C.S.A. 2009. Evaluasi Program Pendidikan.Pedoman Teoretis Praktis Bagi Mahasiswa Dan Praktisi Pendidikan. (Jakarta: Bumi Aksara).

Ashiong P. Munthe. 2015. pentingnya evaluasi program di institusi Pendidikan. Jurnal Scholaria, vol. 5, No. 2

Arikunto, Suharsimi dan Cepi Safruddin Abdul Jabar, evaluasi program pendidikan: pedoman teoritis praktis bagi mahasiswa dan praktisi pendidikan, (Jakarta: Bumi Aksara, 2010), hlm. 22

Bafadal, Ibrahim 2018. Pelaksanaan supervisi manajerial dalam rangka implementasi manajemen berbasis sekolah jurnal administrasi dan manajemen pendidikan, volume 1 , nomor 2 .

Fernandes, H.J.X. 1984. Evaluation of Educational Program. (Jakarta : National Education Planning).

Issac, S. dan Michael, W.B. 1984. Handbook in Research and Evaluation for Education and Behavioral Sciences. (San Diego: Edits Publisher).

Hasanah, Umi et al. 2015. Analisis Pelaksanaan Evaluasi Pembelajaran Biologi

Kelas X Semester Genap 2013/2014 Di Sman Kota Blitar. Jurnal Pendidikan Biologi Volume 7, Nomor 1. 
Hermawan, Acep Metodologi Pembelajaran Bahasa Arab (Bandung: Remaja Rosdakarya, 2014), 135.

Harimi , Abdal Chaqil, Pembelajaran Maharah Bahasa Arab Berbasis Inklusif (Analisis Kebutuhan Peserta Didik Tunanetra Dalam Pembelajaran Keterampilan Berbahasa Arab),tarling: journal of language education, Vol. 1 No. 2

Hamid ,Sholeh, Metode Edutainment (Jogjakarta: Penerbit DIVA Press, 2014), 217-233.

Kinayungan, Irna Et. Al, Efektivitas penerapan Metode Permainan Happy

Kingdom Pada Materi Keanekaragaman Makhluk Hidup Terhadap

Aktivitas Dan Hasil Belajar Siswa Smp, Journal Of Biology Education 5(3) (2016): 230-236

KBBI online. 2019. https://kbbi.web.id/evaluasi. Diakses pada tgl 15/04/.

Mawaddah Bako, Fitri dkk. 2018. pengawasan dan evaluasi program Bahasa

Arab di pondok pesantren. jurnal imla', vol. 3, No. 1.

Maryani, ika. 2014. Evaluasi Pelaksanaan Program Sekolah Adiwiyata Ditinjau

Dari Aspek Kegiatan Partisipatif Di Sdn Ungaran I Yogyakarta. jurnal pemikiran dan pengembangan sd, jilid 1.

ma'ruf, Abdullah. 2014. Manajemen dan evaluasi kinerja karyawan. (Yogyakarta:

Aswaja Pressindo).

Rusydi Ananda \& Tien Rafida. 2017.pengantar evaluasi program Pendidikan.

Medan: perdana publishing.

Setyawan, Edi Cahya. 2015. Desain Evaluasi Program Pembelajaran Bahasa

Arab. Jurnal Komunikasi dan Pendidikan Islam, Volume 4, Nomor 1.

Sugiyono. 2015. Metode penelitian Pendidikan, pendekatan kuantitatif, kualitatif dan $R \& D$. (Bandung: alfabeta).

Purwanto dan Suparman, A. 1999. Evaluasi Program Diklat.( Jakarta:STIA-LAN Press). 